\title{
PENGARUH MEDIASI KEPERCAYAAN PADA HUBUNGAN ANTARA KOLABORASI SUPPLY CHAIN DAN KINERJA OPERASI
}

\author{
Amak M. Yaqoub \\ Department of Management, Faculty of Economic and Business, Universitas Airlangga, Surabaya, Indonesia \\ Email: amakyaqoub@yahoo.co.id
}

\begin{abstract}
Abstrak
Penelitian ini bertujuan menguji peranan mediasi kepercayaan antar-organisasi pada hubungan antara kolaborasi supply chain dengan kinerja operasi. Praktik kolaborasi diukur menggunakan variabel-variabel berbagi informasi, sinkronisasi pengambilan keputusan, serta penggabungan menaknisme insentif. Hasil penelitian menunjukkan, terdapat hubungan positif antara praktik kolaborasi dengan kepercayaan antar organisasi, serta kepercayaan antar organisasi dengan kinerja operasi. Saat model penelitian memasukkan variabel kepercayaan antar-organisasi, hubungan langsung antara praktik-praktik kolaborasi dan kinerja operasi menjadi tidak signifikan. Hal ini mengkonfirmasi peranan mediasi kepercayaan antar-organisasi.
\end{abstract}

Kata Kunci: Supply Chain, Kolaborasi Supply Chain, Kepercayaan Antar-Organisasi, Kinerja Operasi.

\begin{abstract}
This study aims to investigate the mediating role of interorganizational trust on the relationship between supply chain collaboration and operation performance. Supply chain collaboration measured using second order variables; information sharing, incentive alignment, and decision synchronization. Hypotheses testing using SmartPLS confirm positive relationship between supply chain collaboration and interorganizational trust as well as interorganizational trust and operations performance. The direct relationship between supply chain collaboration and operation performance was not significant. These support the mediating role of interorganizational trust.
\end{abstract}

Keywords: Supply Chain, Supply Chain Collaboration, Interorganizational Trust, Operation Performance.

\section{PENDAHULUAN}

Sebagai efek dari semakin kompleksnya persaingan bisnis, ketergantungan antar perusahaan yang tergabung dalam suatu jaringan rantai pasok semakin kuat. Beberapa tahun terakhir literatur manajemen banyak menarik kesimpulan bahwa bergantung pada kekuatan individual perusahaan belum cukup untuk menciptakan daya saing yang berkelanjutan (Hamel \& Breen, 2007). Oleh karena itu, aplikasi Supply chain Management (SCM) yang solid, harus dilakukan untuk mempertahankan eksistensi bisnis (Miles $\&$ Snow, 2007).

Simchi-Levi et al. (2007) mendefinisikan SCM sebagai serangkaian pendekatan yang digunakan untuk, secara efisien, mengkolaborasikan pemasokpemasok, manufaktur, warehouse, dan retailer sehingga mampu memproduksi dan mendistribusikan produk dalam jumlah yang tepat, lokasi yang tepat, dan waktu distribusi yang tepat. Kolaborasi yang prima dipercaya mampu meminimalisasi biaya operasional untuk mencapai kepuasan konsumen.

Salah satu kata kunci dalam SCM adalah terjalinnya kolaborasi yang kokoh antar pihak dalam sebuah rangkaian supply chain. Kolaborasi menjadi istilah umum yang sering digunakan untuk menggambarkan suatu hubungan kerja sama yang dilakukan dua atau lebih pihak. Wood dan Gray (1991) menggambarkan kolaborasi sebagai suatu proses yang mana pihak yang terlibat memandang aspekaspek perbedaan dari suatu masalah serta menemukan solusi dari perbedaan tersebut dan keterbatasan pandangan mereka terhadap apa yang dapat dilakukan.

Untuk mengukur tingkat kolaborasi suatu supply chain, Simatupang dan Sridharan (2004a) menawarkan penggunaan indeks yang disebut sebagai praktikpraktik kolaborasi, yang memiliki tiga faktor penting, yaitu berbagi informasi (information sharing), sinkronisasi pengambilan keputusan (decision synchronization) dan keterkaitan masing-masing pihak dalam 
kolaborasi terhadap aturan pemberlakuan insentif (incentive alignment).

Dalam literatur supply chain yang lain, salah satu hal yang paling penting untuk dimiliki masingmasing perusahaan dalam suatu jejaring rantai pasok adalah kepercayaan antar organisasi (Chopra \& Meindl, 2007). Kwon dan Taewon (2004) menyebutkan bahwa kesuksesan pada performa perusahaan (operation performance) dalam supply chain juga berasal dari tingginya nilai kepercayaan dan komitmen yang kuat antar partner dalam supply chain.

Penelitian dalam ranah strategi aliansi juga menyebutkan bahwa kemungkinan kegagalan bisa lebih besar terjadi pada hubungan dengan tingkat kepercayaan yang rendah (Kwon \& Taewon, 2004). Sementara itu, Katinka dan Koopman (2003) menggaris bawahi bahwa hubungan yang disertai dengan kepercayaan dalam domain inter maupun intraorganisasi mampu mendukung suksesnya strategistrategi kerjasama perusahaan seperti co-operation maupun collaboration.

Berdasarkan beberapa uraian tersebut, penelitian ini ingin menguji secara empiris peranan kepercayaan antar organisasi terhadap hubungan antara praktekpraktek kolaborasi dengan kinerja organisasi. Diharapkan, hasil penelitian ini akan melengkapi model pengukuran indeks kolaborasi yang disampaikan oleh Simatupang dan Sridharan (2004b), dengan memasukkan variable yang bersifat keperilakuan, yaitu kepercayaan antar organisasi.

\section{LANDASAN TEORI DAN HIPOTESIS}

Supply chain didefinisikan sebagai bagianbagian bisnis yang terlibat baik secara langsung maupun tidak langsung dalam tujuan memenuhi permintaan konsumen, yang mana di dalamnya tidak hanya ada manufaktur dan suplier saja, Akan tetapi, juga meliputi transportasi, warehouse, retail, bahkan konsumen (Chopra \& Meindl, 2007). Sasaran dari setiap supply chain adalah meningkatkan atau memaksimalkan seluruh nilai yang dihasilkan oleh perusahaan. Nilai tersebut didapatkan dari penurunan biaya seiring dengan peningkatan kualitas produk yang dihasilkan. Chopra dan Meindl (2007) menyatakan, bahwa nilai yang dihasilkan dari supply chain adalah selisih antara nilai akhir produk yang dirasakan konsumen dengan biaya membangun supply chain.

Harrison dan Van Hoek (2008) turut mendefinisikan SC sebagai jaringan partner yang merubah komoditas dasar (upstream) secara bersamaan menjadi barang jadi (downstream) yang dinilai oleh konsumen akhir. Konsep supply chain mengintegrasikan secara efisien antara pemasok, perusahaan manufaktur, pergudangan, dan toko, sehingga barang yang diproduksi dan didistribusi dengan kualitas, lokasi, dan waktu yang tepat, untuk meminimumkan biaya-biaya pada kondisi yang memuaskan kebutuhan tingkat pelayanan (Simatupang \& Sridharan, 2004a).

Manfaat lainnya yang dapat diperoleh dari SCM antara lain adalah mengurangi persediaan barang dengan berbagai cara, menjamin kelancaran penyediaan barang, mulai dari barang asal (pabrik pembuat), pemasok, perusahaan sendiri, pedagang besar, pengecer, sampai konsumen terakhir. Tujuan lain dari SCM adalah untuk menjamin kesatuan gerak dari jumlah dan kualitas yang memadai pada persediaan yang meliputi banyak hal seperti perencanaan dan komunikasi.

Kolaborasi dilakukan dengan mengumpulkan berbagai pihak dengan kepentingan yang berbeda untuk menghasilkan visi bersama, membangun kesepakatan mengenai suatu isu atau masalah, menciptakan solusi untuk masalah tersebut, dan mengedepankan nilai-nilai bersama untuk menghasilkan keputusan yang menguntungkan semua pihak (Simatupang \& Sridharan, 2008). Kolaborasi supply chain menghubungkan dua atau lebih anggota supply chain dalam membangun komitmen dan mempertahankan proses hubungan dengan sasaran strategis, yang mana mereka menggunakan kemampuan intinya untuk menangani perubahan dan tantangan yang sesuai (Bowersox et al., 2003).

Matthew dan Cheung (2008) mengemukakan manfaat dari kolaborasi supply chain yaitu: pertama, kolaborasi meningkatkan pembagian keuntungan. Kedua, kolaborasi yang semakin meningkat mampu menurunkan beban-beban biaya perusahaan. Ketiga, kolaborasi partnership secara jangka panjang adalah solusi yang terbaik untuk mengembangkan prosesproses bisnis, berikut menurunkan biaya serta penambahan nilai bagi partner. Menurut Simatupang dan Sridharan (2004a), konsep kolaborasi dikategorikan dalam tiga dimensi yang saling berhubungan yaitu Information sharing, Decision synchronisation, Incentive alignment.

Information sharing adalah intensitas dan kappasitas perusahaan dalam interaksinya untuk saling berbagi informasi kepada partner berkaitan dengan strategi-strategi bisnis bersama (Simatupang \& Sridharan, 2008). Simatupang dan Sridharan (2008) menjelaskan bahwa Information sharing memungkinkan anggota rantai pasok untuk mendapatkan, menjaga, dan menyampaikan informasi yang dibutuhkan untuk memastikan pengambilan keputusan menjadi efektif, Information sharing merupakan faktor yang mampu mempererat elemen-elemen kolaborasi secara keseluruhan. 
Selanjutnya, struktur utama dari decision synchronisation adalah menyediakan panduan/ framework bagaimana cara untuk merencanakan dan mengimplementasikan proses-proses yang baik bagi tiap anggota dalam supply chain (Simatupang \& Sridharan, 2004b). Decision synchronisation didefinisikan sebagai sikap untuk memfasilitasi koordinasi pada perencanaan dan eksekusi keputusan antara anggota supply chain terkait (Simatupang et al., 2004). Definisi ini didukung oleh Lee (2002) bahwa pembuatan keputusan yang bersifat independen hanya akan berkontribusi pada kinerja pengambilan keputusan yang kurang optimal dan hanya berpengaruh pada bagian yang melakukannya saja, sedangkan pengambilan keputusan bersama-sama menghasilkan keuntungan yang sinergis pada anggota supply chain.

Adapun cara membuat anggota supply chain berpartisipasi dalam kolaborasi adalah suatu hal yang sulit. Incentive alignment bertujuan untuk menyediakan mekanisme untuk menyetarakan kembali keuntungan dan beban bersama yang terjadi dalam proses perubahan pada supply chain (Simatupang \& Sridharan, 2004a). Incentive alignment adalah sikap menghadapi permasalahan dalam memotivasi anggota yang berpartisipasi dalam menciptakan nilai yang menguntungkan seluruh anggota. Incentive alignment adalah aktivitas berbagi biaya, resiko, dan keuntungan antar anggota yang berpartisipasi dalam SC bisnisnya (Simatupang \& Sridharan, 2008).

Kepercayaan didefinisikan sebagai suatu sikap bahwa kebutuhan satu pihak akan dipenuhi di masa mendatang oleh tindakan-tindakan yang dikerjakan oleh pihak lain (Dash et al., 2007). Kepercayaan disebutkan dalam berbagai penelitian hubungan kerjasama sebagai variabel penentu kesuksesan dan kualitas hubungan yang berjangka panjang (Jonsson \& Zineldin, 2003). Bahkan dalam mengelola rantai pasokan, Heizer dan Render (2004) mengatakan bahwa kepercayaan merupakan hal yang sangat penting dalam rantai pasokan yang efektif dan efisien.

Kepercayaan dirasakan semakin penting dalam sebuah hubungan antar organisasi. Tanpa kepercayaan, sebuah hubungan antara klien dan suplier tidak pernah berjalan untuk memaksimalkan kekuatan potensialnya. Kepercayaan digambarkan sebagai sebuah kesediaan untuk mengambil resiko, dan kepercayaan akan timbul apabila sebuah kelompok saling percaya dan berintegrasi dalam berinteraksi sesama partner (Kwon \& Taewon, 2004)

Kepercayaan dianggap menjadi penting dalam hubungan antar organisasi (Blomqvist \& Levy, 2006). Kepercayaan antar organisasi dibutuhkan dalam kolaborasi antar organisasi tersebut untukmelakukan aktivitas operasional maupun merencanakan rumusan strategi, seperti melakukan riset pengembangan produk, usaha dalam melakukan pengiriman barang secara just in time, atau relationship marketing (Dodgson, 1993). Sydow dan Windeler (1998) berpendapat bahwa kepercayaan antar organisasi juga dimanifestasikan pada keyakinan bahwa para partner memiliki kemampuan tertentu.

Kepercayaan bisa dilihat dari dua sisi sekaligus, yaitu sebagai fasilitator terbentuknya kolaborasi melalui keterbukaan komunikasi, saling berbagi informasi, dan manajemen konflik (Blomqvist \& Levy, 2006). Hal tersebut menjadikan kepercayaan sebagai kebutuhan utama dalam membangun kooperasi antar organisasi (Blomqvist \& Levy, 2006). Pandangan yang lain menyebutkan bahwa kepercayaan merupakan hasil dari interaksi-interaksi berlang antar anggota organisasi. Dalam pandangan ini, kepercayaan hanya akan tumbuh setelah terjadinya proses interaksi (Chopra \& Meindl, 2007).

Penelitian ini lebih memandang kepercayaan dari sudut pandang kedua, yaitu sebagai akibat dari interaksi yang berkelanjutan. Hal ini disebabkan, kolaborasi yang terbentuk dalam suatu supply chain tidak selalu diinisiasi oleh kepercayaan. Pada awalnya, ada kemungkinan kolaborasi tersebut berdasar pada perjanjian kontrak atau keterpaksaan untuk mendapatkan sumber daya khas yang dimiliki oleh rekan dalam berkolaborasi. Kepercayaan akan timbul setelah terjadinya interaksi berulang.

Simatupang dan Sridharan (2005) menjabarkan tiga kriteria dalam pengukuran kinerja perusahaan dalam supply chain yang diambil dari hasil penelitian Ramdas dan Spekman (2000), antara lain adalah fulfilment, inventory, dan responsiveness. Fulfilment berfungsi untuk mengidentifikasi sejauh mana praktik kolaborasi perusahaan dalam jaringan rantai pasok mampu melakukan pemenuhan permintaan (fulfilme$n t)$ kepada konsumen yang meliputi prosentase ketepatan waktu pengiriman barang atau bahkan sebelum waktu yang dijanjikan, ketepatan spesifikasi barang yang diminta, dan kesesuaian kuantitas barang yang diminta.

Inventory berfungsi untuk mengidentifikasi sejauh mana praktik kolaborasi perusahaan dalam jaringan rantai pasok mampu melakukan pengelolaan persediaan yang meliputi tingkat perputaran persediaan, pengurangan jumlah persediaan, dan pengurangan biaya persediaan. Selanjutnya responsiveness berfungsi untuk mengidentifikasi sejauh mana praktik kolaborasi perusahaan dalam jaringan rantai pasok mampu merespon permintaan konsumen yang meliputi tingkat pengurangan waktu tunggu, fleksibilitas dalam mengakomodasi permintaan, dan kepekaan terhadap permintaan konsumen. 
Ketiga dimensi yang dikemukakan oleh Simatupang dan Sridharan (2005) bisa dijadikan pengukuran kinerja supply chain suatu perusahaan berdasarkan perspektif strategi operasi yang disampaikan Slack et al. (2004), yaitu pengukuran kinerja yang berdomain sumber daya, kemampuan operasional, serta proses operasional. Dalam penelitian ini, kinerja sumber daya diukur menggunakan inventory performance, kemampuan operasional diukur dengan fulfilment, sedangkan proses operasional diukur dengan responsiveness.

\section{Hubungan Kolaborasi Supply chain dengan Kepercayaan Antar-organisasi}

Dalam kebanyakan literatur supply chain, terminologi kolaborasi dan integrasi telah sering dikaitkan. Kwon dan Taewon (2004) menyatakan bahwa strategi aliansi akan gagal apabila tidak ada kepercayaan selama berbisnis antara partner bisnis tersebut. Hubungan yang disertai dengan kepercayaan antar anggota inter maupun intra-organisasi mampu mendukung suksesnya strategi-strategi kerjasama perusahaan seperti co-operation maupun collaboration. Melihat keterkaitan teoritis antara kepercayaan antar organisasi dengan kolaborasi dalam supply chain, maka penelitian menetapkan hipotesis pertama:

$\left(\mathrm{H}_{1}\right)$ Terdapat hubungan positif antara praktik-praktik kolaborasi dalam supply chain dengan kepercayaan antar organisasi.

\section{Hubungan Kepercayaan Antar-organisasi dengan Kinerja Operasi}

Chopra dan Meindl (2007) mengatakan bahwa kepercayaan antar organisasi mampu membantu meningkatkan kinerja supply chain dalam beberapa hal yaitu: pertama saling berbagi informasi seringkali diimplementasikan untuk membantu peningkatan kinerja (information sharing). Kemudian visi, misi dan strategi bersama sering diupayakan dalam pencapaian tujuan bersama (incentive alignment). Kemudian koordinasi pengambilan keputusan dalam produksi dan distribusi (joint decision making). Selanjutnya dalam hal peningkatan produktivitas supply chain secara keseluruhan, bagian-bagian dalam supply chain seringkali melakukan peramalan bersama (joint forecasting)

Simatupang dan Sridharan (2004a) mengatakan kolaborasi supply chain terbentuk dari tiga unsur yaitu information sharing, decision synchronisation, dan incentive alignment.
Chopra dan Meindl (2007) mengatakan bahwa unsur tersebut berkaitan dengan peningkatan kinerja yang terjadi akibat adanya kepercayaan antar organisasi. Dari beberapa sudut pandang teoritis di atas dapat disimpulkan bahwa berkolaborasi dalam supply chain ataupun dalam konteks peningkatan kinerja, kepercayaan antar organisasi mutlak harus diterapkan dalam tiap interaksi di supply chain.

Melihat keterkaitan teoritis antara kepercayaan antar organisasi dengan kinerja operasi dalam supply chain, maka penelitian menetapkan hipotesis kedua:

$\left(\mathrm{H}_{2}\right)$ Terdapat hubungan positif antara kepercayaan antar organisasi dengan kinerja operasional perusahaan.

\section{METODE PENELITIAN}

Penelitian ini merupakan penelitian dasar yang menggunakan pendekatan kuantitatif. Penelitian ini ditekankan pada pengujian teori-teori tertentu melalui pengukuran pada variabel-variabel penelitian dan melakukan analisis data dengan prosedur statistik dengan menggunakan data-data terukur yang ada untuk dapat menghasilkan kesimpulan yang dapat digeneralisasikan. Tahapan konseptualisasi berupa identifikasi dimensi-dimensi pengukuran dalam kolaborasi supply chain (information sharing, decision synchronisation, dan incentive alignment), kinerja operasi (fulfilment, responsiveness, dan inventory performance), dan kepercayaan antar organisasi telah dilakukan. Kemudian konstruk-konstruk alat ukur tersebut dikembangkan dan dicari tingkat hubungan antar masing-masing variabelnya.

Pengumpulan data dilakukan melalui penyebaran kuesioner dengan pemilihan responden menggunakan teknik non probability. Metode analisis data yang digunakan adalah menilai Outer Model atau Measurement Model (termasuk di dalamnya uji kualitas data yang meliputi uji validitas dan reliabilitas), menilai Inner Model atau Structural Model, uji validitas model keseluruhan dengan goodness of fit, uji hipotesis serta pembahasannya. Pengujian hipotesis pada penelitian ini menggunakan pendekatan Structural Equation Model (SEM) berbasis Partial Least Square (PLS). PLS adalah metode alternatif dengan pendekatan berbasis varian atau komponen yang berorientasi pada prediksi model (Yamin \& Kurniawan, 2009). Yamin dan Kurniawan (2009) menjelaskan bahwa PLS dapat berkerja untuk model hubungan konstrak laten dan variabel manifest (manifest variable atau indikator) yang bersifat reflektif dan formatif. Gambar model analisis untuk penelitian ini terlihat pada Gambar 1. 


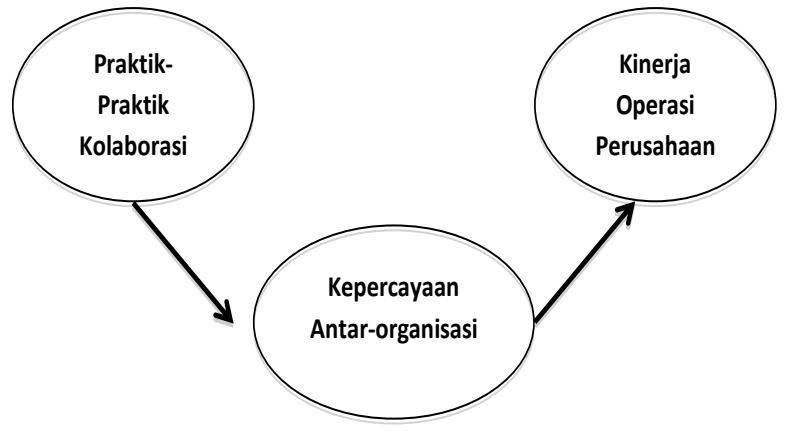

Gambar 1. Model Penelitian

Kolaborasi supply chain adalah sebuah konsep yang menghubungkan dua atau lebih anggota SC dalam membangun komitmen dan mempertahankan proses hubungan dengan sasaran strategis, yang mana mereka menggunakan kemampuan intinya untuk menangani perubahan dan tantangan yang sesuai (Bowersox et al., 2003). Menurut Simatupang dan Sridharan (2005) indikator-indikator variabel yang digunakan berdasarkan tiga dimensi utama yaitu berbagi informasi (information sharing), pengambilan keputusan bersama (decision synchronisation), keselarasan insentif (incentive alignment). Information sharing adalah intensitas dan kapasitas suatu perusahaan dalam berbagi informasi dalam usaha pencapaian tujuan dan strategi-strategi bersama (Simatupang \& Sridharan, 2008). Decision synchronisation didefinisikan sebagai sikap untuk memfasilitasi koordinasi pada perencanaan dan pengeksekusian keputusan antar anggota SC terkait (Simatupang et al., 2004). Incentive alignment adalah aktivitas berbagi biaya, resiko, dan keuntungan antara anggota yang berpartisipasi dalam SC bisnisnya (Simatupang \& Sridharan, 2008).

Kemudian variabel Kinerja operasi (operation performance) adalah suatu ulfillm laten yang mampu mengukur dan mengevaluasi kinerja operasi perusahaan tersebut. Ramdas dan Spekman (2000) dan Simatupang dan Sridharan (2005) menjabarkan tiga kriteria dalam pengukuran kinerja operasi perusahaan pada supply chain yaitu fulfillment, inventory performance, dan responsiveness. Fulfilment mengidentifikasi sejauh mana perusahaan mampu melakukan pemenuhan permintaan (fulfilment) kepada konsumen. Inventory performance mengidentifikasi sejauh mana perusahaan mampu melakukan pengelolaan persediaan. Responsiveness mengidentifikasi sejauh mana perusahaan mampu merespon permintaan konsumen.

Selanjunya variabel kepercayaan antar organisasi (interorganizational trust) adalah unsur kepercayaan antar organisasi yang dibutuhkan dalam kolaborasi antar organisasi yang terlibat (Dodgson, 1993). Pertanyaan yang digunakan pada kepercayaan antar organisasi terlampir. Pertanyaan-pertanyaan tersebut diukur dengan menggunakan skala likert satu sampai tujuh. Angka satu adalah setuju dan angka tujuh adalah tidak setuju. Alasan penulis menggunakan skala likert satu sampai tujuh adalah karena tingkat expertise responden tinggi yang mana mereka semua adalah para pejabat direksi dan bahkan pemilik perusahaan yang berkecimpung langsung dalam perusahaan khususnya berkaitan dengan hal hubungan suplier-retailer atau retailer-suplier.

Responden penelitian adalah anggota perusahaan yang meliputi manajer umum, pemilik, dan jajaran direksi serta staff administrasi. Pengiriman 80 kuesioner dengan cara diantar langsung dilakukan tanggal 26 Maret 2012 pada responden yang dijelaskan sebelumnya di daerah Jawa Timur dan Kalimantan Selatan. Penyebaran kuesioner di wilayah Jawa Timur sebanyak 40 kuesioner, dan wilayah Kalimantan Selatan sebanyak 40 kuesioner. Penyebaran masing-masing wilayah berjumlah 40 karena diharapkan jumlah pengembalian kuesioner juga seimbang antara wilayah tersebut. Wilayah Jawa Timur mewakili area pulau Jawa dan wilayah Kalimantan Selatan mewakili area luar pulau Jawa.

Tanggal cut off keterlambatan kuesioner adalah tanggal 16 April 2012. Pengembalian kuesioner sebelum tanggal cut off sebanyak 45 kuesioner yaitu 25 kuesioner dari wilayah Jawa Timur dan 20 dari wilayah Kalimantan Selatan. Pengembalian kuesioner sesudah tanggal cut off hanya 1 kuesioner yaitu berasal dari wilayah Jawa Timur. Dari data deskriptif di atas bisa disimpulkan bahwa hampir seluruh pengembalian kuesioner terjadi tepat waktu dan hanya 1 kuesioner yang melebihi tanggal cut off yang mana hal ini menjelaskan bahwa para responden memiliki kedisiplinan waktu dalam hal pengembalian kuesioner dan antusiasme yang tinggi dalam membantu penelitian ini dari segi pemberian respon kuesioner yang nantinya akan diteliti. Adapun deskripsi rincian kuesioner yang digunakan dapat dilihat pada Tabel 1.

\section{Tabel 1. Rincian Kuesioner Yang Digunakan}

\begin{tabular}{lcc}
\hline \multicolumn{1}{c}{ Keterangan } & Jumlah & Total \\
\hline Total kuesioner yang kembali & & 46 \\
Kuesioner yang tidak digunakan & 4 & \\
Total kuesioner yang digunakan & & 42 \\
$\begin{array}{l}\text { Tingkat pengembalian (respon rate) } \\
(46 / 80 \times 100 \%)\end{array}$ & $57,5 \%$ \\
$\begin{array}{l}\text { Tingkat pengembalian yang } \\
\text { digunakan (useble respon }\end{array}$ & \\
rate)(42/80 x 100\%) & $52,5 \%$ \\
\hline
\end{tabular}

Sumber: Data Primer diolah 2012 
Tabel 1 tersebut menginformasikan tingkat pengembalian kuesioner (response rate) yaitu sebesar 57,5\% dan tingkat pengembalian kuesioner yang digunakan (usable response rate) yaitu sebesar $52,5 \%$. Empat kuesioner tidak dimasukkan dalam analisis lebih lanjut karena ketidaklengkapan data. Setelah data tersebut tertabulasi dan diolah dengan menggunakan SmartPLS serta konstruk-konstruk yang memiliki nilai outer loading di bawah 0,5 dihapus, maka hasil measurement model masingmasing variabel terlihat pada Table 2 .

Dari Tabel 2 dapat dilihat nilai t-statistik untuk masing-masing konstruk setiap variabel seluruhnya sudah berada di atas nilai 1,96 atau t-hitung > t-tabel. Dapat disimpulkan bahwa semua variabel sudah memenuhi syarat dari kecukupan model atau Discriminant Validity. Kemudian dilakukan uji relialibilitas data menggunakan cronbach alpha hasil algortihma PLS. Suatu konstruk dikatakan reliabel jika memberikan nilai cronbach alpha $>0,60$. Semua variabel yang diteliti memiliki nilai cronbach alpha di atas persyaratan minimal, yaitu decision synchronisation $(0,824839)$, incentive alignment $(0,653747)$, information sharing $(0,807676)$, kepercayaan antar-organisasi $(0,684307)$, kinerja operasional $(0,782881)$, dan praktik-praktik kolaborasi $(0,903931)$.

Kemudian outer model juga menganalisis nilai cross loading yang menunjukkan besarnya korelasi antara setiap konstruk dengan indikatornya dan indikator dari konstruk blok lainnya. Suatu model pengukuran memiliki discriminnant validity yang baik bila korelasi antara konstruk dengan indikatornya lebih tinggi daripada korelasi dengan indikator dari

Tabel 2. Rincian Measurement Model

\begin{tabular}{|c|c|c|c|}
\hline Item-item pengukuran & $\begin{array}{c}\text { Original } \\
\text { Sample }\end{array}$ & $\begin{array}{l}\text { Standard } \\
\text { Deviation } \\
\end{array}$ & T Statistics \\
\hline \multicolumn{4}{|l|}{ Variabel Information Sharing } \\
\hline Agenda promosi yang akan dilakukan & 0,822562 & 0,027359 & 30,065866 \\
\hline Prediksi atau peramalan jumlah permintaan & 0,747548 & 0,052003 & 14,375 \\
\hline Perubahan harga jual & 0,608149 & 0,066698 & 9,117929 \\
\hline Biaya persediaan produk & 0,691142 & 0,046018 & 15,018951 \\
\hline Hambatan dalam menerima produk yang didistribusikan & 0,630457 & 0,073056 & 8,629741 \\
\hline Status order tracking & 0,656846 & 0,0783 & 8,38889 \\
\hline Jadwal pengiriman produk & 0,597085 & 0,087094 & 6,855661 \\
\hline \multicolumn{4}{|l|}{ Variabel Decision Synchronisation } \\
\hline Penentuan kuantitas order yang optimal & 0,819719 & 0,038423 & 21,33411 \\
\hline Pembuatan perencanaan jangka panjang & 0,57831 & 0,066805 & 8,6567 \\
\hline Peramalan/prediksi permintaan komponen atau produk & 0,780176 & 0,057481 & 13,57286 \\
\hline Perencanaan agenda promosi & 0,846383 & 0,028722 & 29,467795 \\
\hline Kebijakan harga jual produk & 0,795989 & 0,027569 & 28,873061 \\
\hline \multicolumn{4}{|l|}{ Variabel Incentive Alignment } \\
\hline Kesepakatan akan perubahan kebijakan order & 0,587733 & 0,076906 & 7,642272 \\
\hline Pembagian biaya dan keuntungan pada program bersama khusus untuk konsumen & 0,847562 & 0,027185 & 31,177191 \\
\hline Pembagian keuntungan dari efisiensi biaya persediaan & 0,860105 & 0,039812 & 21,60403 \\
\hline \multicolumn{4}{|l|}{ Variabel Kepercayaan Antar Organisasi } \\
\hline Pertanyaan T 5 & 0,696252 & 0,10256 & 6,788727 \\
\hline Pertanyaan T 7 & 0,810764 & 0,053735 & 15,088141 \\
\hline Pertanyaan T 8 & 0,736531 & 0,074401 & 9,899441 \\
\hline Pertanyaan T 9 & 0,615459 & 0,096045 & 6,408041 \\
\hline \multicolumn{4}{|l|}{ Variabel Kinerja Operasi } \\
\hline \multicolumn{4}{|l|}{ Fulfilment } \\
\hline Kesesuaian pengiriman barang pada atau bahkan sebelum waktu yang dijanjikan & 0,608706 & 0,147922 & 4,115035 \\
\hline Kesesuaian barang yang dikirim dengan barang yang diminta konsumen & 0,787719 & 0,076236 & 10,332681 \\
\hline Kesesuaian kuantitas barang yang dikirm dengan yang diminta konsumen & 0,767455 & 0,078266 & 9,805688 \\
\hline \multicolumn{4}{|l|}{ Inventory Performance } \\
\hline Perputaran persediaan & 0,648906 & 0,115065 & 5,639462 \\
\hline Penurunan jumlah persediaan yang disimpan & 0,532649 & 0,137155 & 3,883567 \\
\hline \multicolumn{4}{|l|}{ responsiveness } \\
\hline Fleksibilitas dalam mengakomodasi perubahan permintaan & 0,579285 & 0,122865 & 4,714796 \\
\hline Kepekaan terhadap permintaan konsumen & 0,628055 & 0,173774 & 3,614208 \\
\hline
\end{tabular}


konstruk blok lainnya (Yamin \& Kurniawan, 2011). Indikator konstruk DS 1, DS 2, DS 3, DS 4, DS 5, dan DS 6 lebih tinggi berkorelasi dengan variabel decision synchronisation. Kemudian F 1, F 2, F 3, IP 1, IP 2, R 2, R 3 berkorelasi lebih tinggi dengan variabel operation performance. Demikian halnya dengan indikator konstruk lainnya yang berkorelasi lebih tinggi dengan masing-masing variabelnya, maka model pengukuran ini memiliki discriminnant validity yang baik sesuai dengan pendapat Yamin dan Kurniawan (2011) di atas.

Metode lain untuk menilai Discriminant Validity pada outer model adalah dengan melihat nilai composite reliabilty dari blok indikator yang mengatur konstruk. Discriminant Validity dikatakan baik jika bernilai di atas 0,70 dan dikatakan sangat memuaskan apabila di atas 0,80 (Nunnally dan Bernstein, 1994). Semua variabel memiliki nilai composite reliability yang di atas 0,80 dengan spesifikasi decision synchronization $(0,877645)$, incentive alignment $(0,814946)$, information sharing $(0,858276)$, kepercayaan antar organisasi $(0,808455)$, kinerja operasi $(0,838742)$, dan kolaborasi supply chain $(0,918741)$. Selanjutnya, semua variabel dilanjutkan ke tahap analisis selanjutnya yaitu pengujian model struktural (inner model)

Pengujian inner model atau model struktural dilakukan untuk melihat signifikansi hubungan antara konstruk dan $R$-square. Model struktural dievaluasi dengan menggunakan uji $\mathrm{t}$ untuk mengetahui signifikansi dari koefisien parameter jalur struktural. $R$-square untuk mengetahui pengaruh variabel laten eksogen terhadap variabel laten endogen apakah memiliki pengaruh yang substantif. Nilai $R$-square konstruk kepercayaan antar organisasi sebesar 0,061274 , konstruk kinerja operasi sebesar 0,236301, konstruk praktik kolaborasi supply chain sebesar 0,999645. Semakin tinggi R-square, maka semakin besar variabel independen tersebut dapat menjelaskan variabel dependen sehingga semakin baik persaman struktural.

Untuk memvalidasi model secara keseluruhan, maka digunakan goodness of fit $(\mathrm{GoF})$ yang diperkenalkan oleh Tenenhaus et al. (2004). GoF index ini merupakan ukuran tunggal yang digunakan untuk memvalidasi performa gabungan antara model pengukuran (outer model) dan model struktural (inner model). Nilai GoF index diperoleh dari average communalities index dikalikan dengan nilai $\mathrm{R}^{2}$ model. Nilai GoF terbentang antara 0-1 dengan interpretasi 0,1 (GoF kecil), 0,25 (GoF moderat), 0,36 (GoF besar) (Tenenhaus et al., 2004). nilai rata-rata communalities adalah 0,50746; sedangkan nilai rata-rata $\mathrm{R}^{2}$ adalah 0,43241 ; sehingga $\mathrm{GoF}=\sqrt{ } 0,50746 \times 0,43241$ $=0,46843$ (GoF besar). Dari hasil tersebut bisa disim- pulkan bahwa performa antara model pengukuran dan model struktural memiliki GoF yang besar yaitu sebesar 0,46843 (di atas 0,36).

\section{HASIL PENELITIAN DAN PEMBAHASAN}

Untuk menguji hipotesis yang diajukan, dapat dilihat besarnya nilai t-statistik. Batas untuk menolak dan menerima hipotesis yang diajukan adalah $\pm 1,96$, yang mana apabila nilai $t$ berada pada rentang nilai 1,96 dan 1,96 maka hipotesis akan ditolak atau dengan kata lain menerima hipotesis nol $\left(\mathrm{H}_{0}\right)$. Hasil estimasi t-statistik dapat dilihat pada path coefficient (t-statistics) pada Tabel 3.

\section{Tabel 3. Hasil Dari Path Coefficient}

\begin{tabular}{lcccc}
\multicolumn{5}{c}{ (Mean, Standard Deviation, T-Values) } \\
\hline & $\begin{array}{c}\text { Original } \\
\text { Sample }\end{array}$ & $\begin{array}{c}\text { Sample } \\
\text { Mean }\end{array}$ & $\begin{array}{c}\text { Standard } \\
\text { Deviation Statistics }\end{array}$ \\
\hline Itr -> op & 0,441813 & 0,474141 & 0,105498 & 4,18789 \\
scc practice -> itr & 0,247536 & 0,245489 & 0,103429 & 2,39329
\end{tabular}

Sumber: Output SmartPLS 2012

\section{Pengaruh Antara Praktik Kolaborasi SC Dengan Kepercayaan Antar-Organisasi}

Hipotesis pertama $\left(\mathrm{H}_{1}\right)$ menyatakan bahwa terdapat pengaruh positif dalam hubungan praktekpraktek kolaborasi supply chain terhadap kepercayaan antar organisasi. Hasil perhitungan terhadap koefisien parameter antara praktek-praktek kolaborasi supply chain dan kepercayaan antar organisasi menunjukkan ada pengaruh positif $(0,247536)$, dengan nilai tstatistik sebesar 2,39329. Nilai $\mathrm{t}$ statistik tersebut berada jauh di atas nilai kritis $\pm 1,96$, dengan demikian hipotesis pertama $\left(\mathrm{H}_{1}\right)$ diterima.

Temuan ini mendukung hasil penelitian Blomqvist dan Levy (2006) bahwa kepercayaan mampu memfasilitasi komunikasi yang terbuka dan saling berbagi informasi, yang mana saling berbagi informasi (information sharing) menjadi salah satu variabel pendukung kolaborasi dalam supply chain. Begitu juga dengan landasan teori penelitian Blomqvist dan Levy (2006) bahwa kepercayaan menjadi kebutuhan utama dalam membangun koordinasi antar organisasi.

Temuan ini juga memperkuat salah satu teori tentang asal usul tumbuhnya kepercayaan dalam bisnis yaitu sudut pandang pencegahan (deterrence based view) yang dikemukakan oleh Chopra dan Meindl (2007), yaitu menggunakan kontrak formal berkolaborasi terlebih dahulu, untuk membangun kepercayaan antar pihak dan masing-masing pihak 
harus menunjukkan rasa kepercayaannya tersebut secara alami (tidak direkayasa). Demikian pula dengan statement penelitian Kwon dan Taewon (2004) yang menyatakan bahwa upaya untuk berkolaborasi di antara startegi-strategi supply chain adalah salah satu cara terbaik untuk minimalisasi ketidakpastian dan mampu meningkatkan nilai kepercayaan antar maupun intra organisasi yang bersangkutan.

\section{Pengaruh Antara Kepercayaan Antar-Organisasi Dengan Kinerja Operasi}

Hipotesis kedua $\left(\mathrm{H}_{2}\right)$ menyatakan bahwa terdapat pengaruh positif dalam hubungan kepercayaan antar organisasi terhadap kinerja operasi perusahaan. Hasil perhitungan terhadap koefisien parameter antara kepercayaan antar organisasi (itr ) dan kinerja operasi perusahaan (op) menunjukkan ada pengaruh positif $(0,441813)$, dengan nilai t-statistik sebesar 4,18789. Nilai t statistik tersebut berada jauh di atas nilai kritis $\pm 1,96$, dengan demikian hipotesis kedua $\left(\mathrm{H}_{2}\right)$ dapat diterima. Hal ini membuktikan kepercayaan kepada partner bisnis yang tumbuh dari sifat open mind dan sering mengandalkan kerjasama dengan partner secara garis besar mampu meningkatkan kinerja operasi.

Temuan ini mendukung teori tentang asal usul tumbuhnya kepercayaan dalam bisnis yaitu sudut pandang proses (process based view) oleh Chopra dan Meindl (2007), yaitu kepercayaan akan tumbuh dan berkembang seiring meningkatnya jumlah interaksi antar bagian SC. Interaksi yang positif mampu memperkuat keyakinan dalam berkerjasama dengan organisasi lain, yang pada akhirnya kinerja perusahaan meningkat akibat adanya kerjasama tersebut.

Temuan ini juga menguatkan hasil penelitian Barney dan Hansen (1994) bahwa kepercayaan menjadi faktor penting dalam meningkatkan kemampuan kinerja bisnis dan menjadi suatu kekuatan dasar bagi kemampuan bertahan dalam kompetisi bisnis. Begitu juga dengan hasil penelitian Morgan dan Hunt (1994) bahwa kepercayaan dan komitmen telah menghasilkan output berupa peningkatan efisiensi, produktifitas, dan efektifitas kinerja.

Penelitian ini membuktikan secara empiris adanya hubungan antara praktik-praktik Kolaborasi dalam Supply chain dengan kepercayaan antar organisasi serta pengaruh kepercayaan antar organisasi dengan kinerja operasi perusahaan. Temuan tersebut akhirnya membuktikan dan mendukung teori-teori yang mengatakan pentingnya unsur kepercayaan dalam bisnis umumnya, dan kepercayaan antar organisasi dalam hubungan antar organisasi pada khususnya.

Namun apabila koefisien parameter antara praktek-praktek Kolaborasi Supply chain dan Kinerja Operasi Perusahaan dihitung, maka hasilnya tidak menunjukkan pengaruh yang signifikandengan nilai tstatistik sebesar 0,778249. Temuan ini tampak berbeda dengan hasil penelitian terdahulu yang dilakukan oleh Simatupang dan Sridharan (2005) yang mana ada pengaruh positif antara parameter praktekpraktek kolaborasi supply chain dengan kinerja operasi perusahaan. Akan tetapi, jika ditinjau lebih jauh menggunakan model komparasi yang tidak menyertakan variabel kepercayaan antar-organisasi, model penelitian yang diajukan Simatupang dan Sridharan (2005) memiliki nilai yang signifikan.

Dari perbandingan antara hasil penelitian dengan dua model tersebut maka dapat dikonformasi adanya pengaruh mediasi kepercayaan antar organisasi pada hubungan antara praktik-praktik kolaborasi dalam supply chain dengan kinerja operasi. Hal ini sesuai dengan teori Chopra dan Meindl (2007) bahwa dalam konteks peningkatan kinerja operasi yang didukung oleh strategi kolaborasi supply chain, perlu adanya unsur kepercayaan antar organisasi yang menjadi faktor penting dalam berkolaborasi.

\section{SIMPULAN DAN SARAN}

Setelah menemukan bukti empiris terhadap hipotesis-hipotesis yang diajukan, dan agar penelitian dengan tema supply chain ini memiliki kesinambungan terhadap estafet esensi penelitian terdahulu hingga masa mendatang, maka keterbatasan penelitian yang dilanjutkan dengan saran dari penelitian ini adalah sebagai berikut:

Walaupun jumlah sampel penelitian sudah memenuhi ketentuan minimal yaitu berjumlah 42 sampel yang syarat minimalnya adalah 30 sampel, akan lebih kuat apabila didukung data penelitian dengan jumlah sampel yang lebih banyak dari penelitian ini sehingga model penelitian juga bisa dikembangkan lebih mendalam lagi untuk mengkaji ilmu-ilmu manajemen pada umumnya, dan ilmu manajemen operasi dan rantai pasok pada khususnya. Penelitian ini memandang kepercayaan antar organisasi dalam sudut pandang process based view, yang mana kepercayaan dipandang sebagai hasil interaksi secara berkelanjutan. Pada penelitian yang berikutnya perlu untuk melihat pengaruh variabel kepercayaan sebagai antiseden kolaborasi atau variabel moderasi pada hubungan antara praktik kolaborasi dengan kinerja operasi. 


\section{DAFTAR REFERENSI}

Barney, J.B. \& Hansen, M.H. 1994. Trustworthiness as a Source of Competitive Advantage. Strategic Management Journal, 15: 175-190.

Blomqvist, K. \& Levy, J. 2006. Collaboration Capability - A Focal Concept in Knowledge Creation and Collaborative Innovation in Networks. International Journal Management Concept and Phylosophy, 2 (1): 31-48.

Bowersox, D.J., Closs, D.J., Stank, T.P. 2003. How to Master Cross-Enterprise Collaboration. Supply Chain Management Review, 7(4): 18-27.

Chopra, S. \& Meindl, P. 2007. Supply Chain Management: Strategy, Planning, and Operation. New Jersey: Prentice-Hall, Inc.

Dash, S., Brunning, E. \& Kaiyan, K.G. 2007. Antecedents of Long-Term Buyer-Seller Relationships: A Cross Cultural Integration. Academy of Marketing Science Review, 1(11).

Dodgson, M. 1993. Learning, Trust, and Technological Collaboration. Human Relations. 46(1): 77-95.

Hamel, G. \& Breen, B. 2007. The Future of Management. Massachusets, USA: Harvard Business School Press.

Harrison, A. \& Van Hoek, R. 2008. Logistics Management and Strategy: Competing through the Supply Chain. Fourth Edition. Harlow: Pearson Education.

Heizer, J. \& Render, B. 2004. Operations Management. $7^{\text {th }}$ Edition. Englewood Cliffs, NJ: Prentice Hall.

Jonsson, P. \& Zineldin, M. 2003. Achieving High Satisfaction In Supplier-Dealer Working Relationships. Supply Chain Management: An International Journal, 8(3): 224-240.

Katinka, B. \& Koopman, P. 2003. Introduction: Trust Within Organizations. Personnel Review, 32(5): 543-555.

Kwon, I.W.G. \& Taewon, S. 2004. Factors Affecting the Level of Trust and Commitment in Supply Chain Relationships. Journal of Supply Chain Management, 40: 4-14.

Lee, H.L. 2002. Aligning Supply Chain Strategies With Product Uncertainties. California Management Review, 44(4): 105-119.

Matthew, B.M. \& Cheung, M.S. 2008. Sharing Global Supply Chain Knowledge. Sloan Management Review, 49: 67-73.

Miles, R.E. \& Snow, C.C. 2007. Organization Theory and Supply Chain Management. Journal of Operations Management, 25: 459-463.
Morgan, R.M. \& Hunt, S.D. 1994. The CommitmentTrust Theory of Relationship Marketing. Journal of Marketing, 58: 20-38.

Ramdas, K. \& Spekman, R.E. 2000. Chain or Shackles: Understanding What Drives Supply Chain Performance. Interfaces 30: 3-21.

Simatupang, T.M. \& Sridharan, R. 2004a. Benchmarking Scheme For Supply Chain Collaboration. Benchmarking: An International Journal, 11 (1): 9-30.

---oncharking Supply Chain Collaboration: An Empirical Study. Benchmarking: An International Journal, 11 (5): 484-503.

----------. 2005. The Collaboration Index: A Measure For Supply Chain Collaboration. International Journal of Physical Distribution \& Logistics Management, 35 (1).

- 2007. The Architecture Of Supply Chain Collaboration. International Journal of Value Chain Management, 1(3): 304-323. 2008. Design For Supply Chain Collaboration. Business Process Management Journal, 14(3): 401-418.

Simatupang, T.M., Wright, A.C. \& Sridharan, R. 2004. Applying The Theory Of Constraint To Supply Cahin Collaboration. Supply Chain Management: An International Journal, 9 (1): 57-70.

Simchi-Levi, D., Kaminsky, P. \& Simchi-Levi, E. 2007. Designing and Managing the Supply Chain. $3^{\text {rd }}$ Edition. New York, USA: McGraw Hill.

Slack, N., Lewis, M. \& Bates, H. 2004. The Two Worlds of Operations Management Research and Practice: Can They Meet, Should They Meet? International Journal of Operations \& Production Management, 24(4): 372-387.

Sydow, J. \& Windeler, A. 1998. Organizing and Evaluating Interfirm Networks: A Structurationist Perspective on Network Processes and Effectiveness. Organization Science, 9 (3): 265-284.

Tenenhaus, M., Vinzia, V.E., Chatelin, Y.M. \& Lauro, C. 2004. PLS Path Modeling. Computational Statistics \& Data Analysis, 48(1): 159-205.

Wood, D.J. \& Gray, B. 1991. Toward a Comprehensive Theory of Collaboration. Journal of Applied Behavioral Science, 27(2): 139-162.

Yamin, S. \& Kurniawan, H. 2009. Structural Equation Modeling: Belajar Lebih Mudah Teknik Analisis Data Kuesioner Dengan Lisrel-PLS. Jakarta: Salemba Infotek.

-----. 2011. Generasi Baru Mengolah Data Penelitian Dengan Partial Least Square Path Modeling. Jakarta: Salemba Infotek. 